\title{
The Scholarship of Teaching and Learning: Past Lessons, Current Challenges, and Future Visions
}

\section{Kathleen McKinney}

Illinois State University

This chapter reviews the complex history of the scholarship of teaching and learning (SoTL) including SoTL as a social movement and various conceptualizations of the term. Based on extant work, I also discuss past lessons, current challenges, and future directions for SoTL. Additional theorizing and research are needed in many areas. Suggestions related to faculty and organizational development and change are imbedded in this discussion.

\section{INTRODUCTION}

Formal ideas about the scholarship of teaching and learning (SoTL) and re$\mathrm{F}_{\text {lated concepts have been discussed in the field of higher education for over }}$ a dozen years. Yet SoTL work has existed, in many disciplines in higher education, for decades. Consider, for example, the many college-level, disciplinary teaching journals with long histories. In my discipline, this journal is Teaching Sociology, which has been in existence for about 30 years. Though Boyer's (1990) work on the scholarship of teaching concept has received the most attention, others contributed to this early discussion. For example, Shulman coined the phrase pedagogical content knowledge (Shulman, 1987). Pellino, Blackburn, and Boberg (1984) discussed multiple forms of scholarship including the scholarship of pedagogy. Activities and products such as course content and activities were seen as a form of scholarship in Braxton and Toombs's (1982) research. In the discipline of sociology, Goldsmid and Wilson (1980) grappled with the similarities of and standards for research and teaching, and 
argued "collaborative inquiry is at the heart of both activities" (p. 32). In addition, Baker $(1980,1985,1986)$ discussed ideas about the relationships among what we know about teaching as sociologists, and our work and writing about teaching.

The increased prominence of the SoTL in the national higher education arena can be seen through efforts such as the Carnegie Academy for the Scholarship of Teaching and Learning, or CASTL, program; the Carnegie Scholars program; a growing number of local, regional, and national conferences on college teaching and/or SoTL (e.g., sessions at Lilly Conferences; the American Association for Higher Education pre-conference, Rockhurst University's annual SoTL conference); and new SoTL journals, both online and traditional, both general and discipline based (e.g., Journal of Scholarship of Teaching and Learning, Journal of Active Learning, Journal of Student Centered Learning). National disciplinary societies are also showing more interest in supporting SoTL work as seen in cooperative efforts between these societies and the CASTL program. For example, with help from the CASTL program, the American Sociological Association (ASA) brought together about 40 sociologists in the summer of 2000 to discuss and develop position papers on the status of knowledge and research on teaching and learning in the discipline. Finally, a significant number ( 12 of 50 using a narrow definition; 27 of 50 using a broader definition) of the institutional social change projects at the 2002 American Association for Higher Education (AAHE) Summer Academy in Vermont focused on promoting the SoTL. For example, projects dealt with SoTL development opportunities, increasing the quantity and quality of SoTL work, changes in reward structures to recognize SoTL, and involving more students in SoTL work.

Why the growing emphasis on SoTL? Due to changes in the higher education climate we have been reminded that we need to know much more about how, why, and when our students learn. These changes include a renewed focus on teaching across all types of institutions, increasing diversity of the student body, rapid adoption of new instructional technologies, new knowledge about learning and the brain, and additional pressures for the use of assessment data to determine student learning outcomes. In addition, many of us have come to realize that we cannot afford what Shulman (2001) called the great tragedy of teaching-the collective amnesia about what works and why in teaching and learning. SoTL is the primary treatment for preventing this amnesia and creating an up-to-date knowledge base that can be used to improve student learning and development. 
We can look at this growing interest in and support for SoTL as a social movement-not one that is integrated into society as a whole but rather one that is limited in scope and somewhat specific to the institution of higher education (sometimes called an alternative social movement). Over 15 years ago, Mauksch and Howery (1986) articulated the notion of the teaching movement in sociology as a social change movement. A similar argument can be made today for the national/international SoTL movement.

Based on the deprivation/frustration (e.g., Smelser, 1963) and resource mobilization (McCarthy \& Zald, 1977) approaches to social movements, there are a variety of factors that influence and characterize social movements: frustration over a problem or a needed reform, a sense that the problem or change is possible, an ideology, use of networks to recruit members, mobilization of resources including leaders and finances, a sense that the movement has legitimacy, increased awareness of the issues and movement, the ability to fend off counter-movements, existence of allies from outside the movement, and the development of organizations to support the movement.

As we look at recent trends in and the status of SoTL today, we can see many of these same characteristics. There has been increasing concern about the lack of knowledge and insufficient use of such knowledge for teaching and learning in higher education disciplines as well as frustration about the definition, value, and rewards of SoTL. Members of the movement share many beliefs about the legitimacy and positive value of SoTL. Leadership, finances, legitimacy, recruitment of members, and the development of organizations have been mobilized and strengthened through work at universities, AAHE, the Carnegie Foundation, and disciplinary societies. Some of our outside allies are supportive colleagues and administrators not directly involved in SoTL, and private donors or funding agencies willing to provide financial support for SoTL work.

\section{Past Lessons in the Scholarship of Teaching and Learning}

What are some of the key lessons learned during this history of SoTL? First, we have learned, and continue to learn, the importance and value of SoTL to higher education. SoTL contributes to the knowledge base about teaching and learning and is serving as a movement to stimulate networking, research, discussion, and action related to improving teaching and learning.

Second, defining SoTL in a way that makes sense to everyone has been problematic. Many writers have attempted to discuss and refine the SoTL concept (e.g., Baker, 2002; Braxton, Luckey, \& Helland, 2002; Cross \& Steadman, 1996; Darling, 2003; Glassick, Huber, \& Maeroff, 1997; Hutchings \& 
Shulman, 1999; Kreber, 2001 a; Kreber \& Cranton, 2000; Paulsen \& Feldman, 1995; Rice, 1992; Richlin, 1993, 2001; Schön, 1995; Weimer, 1996).

Definitions tend to focus on activities or processes. For example, Illinois State University, as part of its work with the CASTL program, agreed to conceptualize SoTL as a systematic reflection on teaching and learning made public. In work at the Carnegie Foundation and the American Association of Higher Education, the following definition has sometimes been used: "problem posing about an issue of teaching or learning, study of the problem through methods appropriate to the disciplinary epistemologies, applications of results to practice, communication of results, self-reflection, and peer review" (Cambridge, 2001, p. 8). Kreber and Cranton (2000) view SoTL as "ongoing learning about teaching and the demonstration of such knowledge" (p. 478), while Darling (2003) states that SoTL is "work that encourages an empirical examination of teaching in relation to student learning" (p. 47). Richlin (2001) argues, "The scholarship part of the process involves composing selected portions of the investigation and findings [or integration or reflection] into a manuscript to be submitted to an appropriate journal or conference venue" (p. 61). Martin, Benjamin, Prosser, and Trigwell (1999) argue that the scholarship of teaching is three related activities: engagement with the existing knowledge on teaching and learning, self-reflection on teaching and learning in one's discipline, and public sharing of ideas about teaching and learning within the discipline.

Hutchings (2002a) reminds us that SoTL builds on many past traditions in higher education including classroom and program assessment, $\mathrm{K}-12 \mathrm{ac}-$ tion research, the reflective practice movement, peer review of teaching, traditional educational research, and faculty development efforts to enhance teaching and learning. As Kreber (2001b) and others have pointed out, and as her Delphi study indicates, we lack shared language and meaning in this area. Furthermore, many do not use the term SoTL in the way that Boyer (1990) originally conceptualized the scholarship of teaching. Boyer's scholarship of teaching is closer to what many today refer to as scholarly teaching.

Similar to what others have discussed or implied (e.g., Cross and Steadman, 1996; Healey, 2000; Rice, 1992), I believe Boyer's typology of scholarships conflates two dimensions: type of scholarly activity and topic or area of scholarship. That is, he delineated four types of scholarship: discovery, incegration, application, and teaching. Yet, recent views of the concept of SoTL include activities that are discovery, integration, and application where the topic is teaching and learning (usually in higher education and often in terms of a specific discipline). 
Others have reworked Boyer's types. Baker (2002) outlines four roles (discovery, integration, and two forms of application) within his view of the scholarship of teaching. McKenna, Bickle, and Carroll (2002) argue that discovery, integration, application, and teaching are stages in a scholarly process. They point out that the final stage-the production of a scholarly outcome-is missing and is necessary for any work to "count."

Though Rice (1992) acknowledges this overlap of dimensions and points out that the Boyer scholarship types were to be seen as interdependent, I think this aspect of the typology remains problematic. The conflation of the activity and topic dimensions leads to misunderstanding and confusion, and the questioning of SoTL work as legitimate scholarship.

We have also learned that there are many difficulties with the status and structure of SoTL work. Based on observations of my own campus and discussions with colleagues on other campuses, much SoTL work occurs in isolation, undertaken by one or a small number of faculty members within a department, often working alone. What we know from SoTL work is fragmented and not adequately shared. Many faculty and staff members are unaware of the growing number and range of higher education pedagogical journals, sometimes even of the one(s) in their own discipline. Finally, in many places, SoTL work receives little support, reward, or recognition, or is categorized within reward systems as teaching rather than scholarship.

\section{Current Challenges in the SCHOLARSHIP OF Teaching aNd Learning}

Perhaps not surprisingly, many of these past lessons remain current challenges. First, we still struggle with the meaning of SoTL and related terms. Is there a "best" definition? Do we need consensus on a definition? Is SoTL a "field"? How is SoTL related to traditional educational research or to assessment studies? Is SoTL the process and/or the outcomes? Depending on how we conceptualize SoTL, are we doing more of this work than in the past? Is the work "stronger" than in the past? In my own discipline, Chin (2002) recently published a replication of Baker's (1985) work analyzing articles published in Teaching Sociology, in an attempt to categorize those that meet the criteria for scholarship. Chin concludes that there has been modest improvement in the amount and quality of SoTL work in sociology since 1985. The challenge here is to continue the conversation about the nature and meaning of this work, and to find sufficient common ground to allow understanding and collaboration. 
Second, a challenge closely related to the first, is to negotiate distinctions between related key terms: distinctions that impact legitimacy, support, evaluation, and rewards. Though there are close connections among them, it is important to distinguish good teaching from scholarly teaching from the scholarship of teaching and learning. My preference is for the following distinctions (see, also, Darling, 2003; Healey, 2000; Hutchings \& Schulman, 1999; many of the chapters in Kreber, 2001a). Though good teaching has been defined and operationalized in many ways (e.g., student satisfaction ratings, peer observation judgments, self-reflective portfolios), good teaching promotes student learning and other desired student outcomes. Good teaching will support department, college, and institutional missions and objectives. Decades of SoTL and other educational research provide us with a great deal of information on the practices that help promote learning (e.g., Astin, 1993; Chickering \& Gamson, 1987; Pascarella \& Terenzini, 1991).

Scholarly teaching involves taking a scholarly approach to teaching just as we would take a scholarly approach to other areas of knowledge and practice. Scholarly teaching is a process; scholarly teachers view teaching as a profession and the knowledge base on teaching and learning as a second discipline in which to develop expertise. Thus, scholarly teachers do things such as reflect on their teaching, use classroom assessment techniques, engage in systematic course design, update their courses, discuss teaching issues with colleagues, try new teaching techniques, and read and apply the literature on teaching and learning in their discipline. Scholarly teaching is closely linked to reflective practice (e.g., Brookfield, 1995; Schön, 1983, 1987). This conception of scholarly teaching is related to what Boyer (1990) labeled the scholarship of teaching.

The scholarship of teaching and learning goes beyond scholarly teaching and involves the systematic study of reaching and/or learning and the public sharing and review of such work through presentations or publications. Clearly, there is a focus here on the product or outcome. "Study" is broadly defined given disciplinary differences in epistemology and the need for interdisciplinary SoTL. SoTL, then, shares established criteria of scholarship in general, such as that it is made public, can be reviewed critically by members of the appropriate community, and can be built upon by others to advance the field (Shulman, 2001). Ideally, SoTL also involves application and use.

In this view, it is possible that individuals can teach, though probably not with great effectiveness, and not be scholarly teachers. Individuals can practice scholarly teaching but not actually contribute to the knowledge base by conducting and making public their own SoTL work. In many institutions, good 
teaching and scholarly teaching would be rewarded under teaching, while the scholarship of teaching and learning would be rewarded under research/scholarship. Recently, some writers have argued that movement through these three types of activities and beliefs-good teaching, scholarly teaching, and SoTLis a developmental process in a faculty member's career (e.g., Smith, 2001; Weston \& McAlpine, 2001).

Third, then, is the challenge to strengthen the legitimacy of quality SoTL work in terms of its status and its applicability. Bass (1999) offers a provocative discussion of the concept of teaching-learning "problems" and their place in the minds of faculty and in SoTL work. Teaching-learning problems are the 'appropriate topic of ongoing, long-term investigation, not something to be hidden from others or quickly fixed.

Two authors have raised concerns about the current and future status or role of SoTL work. Cross expressed the concern that the scholarship of teaching and learning could become another "tier" in the academic hierarchy-that is, that the perception will be that "those who can't do research in their field, do SoTL, and those that can't do SoTL, teach" (K. P. Cross, personal communication, fall 2002). On the other hand, SoTL might serve as one bridge between our teaching and traditional scholarly roles. SoTL has the potential to increase interest in teaching on the part of those who are primarily traditional researchers, as well as to increase interest in research of those who primarily teach.

In a related vein, Eisenberg (2002), referring specifically to the discipline of sociology, argues that there are two faces in the higher education teaching community. There is the face of the art and practice of teaching and the face of SoTL. Her concern is that there could be a growing gap, or schizophrenia, between these two in terms of collaboration, legitimacy, and support, with a variety of negative consequences. She suggests the need for "educational praxis," "a set of dynamic dialogues and collaborations that serve as the bridge between the practice and art of teaching with the SoTL" (p. G). I certainly agree that scholarly teachers and those scholarly teachers who also engage in SoTL must collaborate. In an ideal view of SoTL, however, this gap between the two faces would not exist, as SoTL would involve application and practical use. This is related to Braxton, Luckey, and Helland's (2002) notion of the purpose of the scholarship of teaching as "the development and improvement of pedagogical practices" (p.106). As we consider ways to increase the legitimacy and value of SoTL work, appropriate and visible application is one key mechanism. 
Another concern has to do with the breadth of the scholarship concept. Are all activities or processes related to our academic lives (teaching, professional service, community service/engagement, research) inherently scholarship? Does such a broad conceptualization undermine the legitimate value of teaching in its own right by implying that teaching has value only if it is labeled scholarly or only if we can define it as scholarship? If we move in the direction of such a broad conception of scholarship, where are the lines between academic activity, scholarly activity, and scholarship? How does this complicate the faculty evaluation process? For example, isn't it possible for a course to be developed in a manner that is not scholarly (e.g., peers are not consulted, curricular literature is not read)? In addition, course development or experimenting with new pedagogies, without characteristics such as reflection, peer review, and public sharing, are clearly worthy of reward but not under the rubric of scholarship.

Braxton, Luckey, and Helland (2002) offer an inventory of the scholarship of teaching that includes both activities/process and outcomes/products, including scholarly activities (e.g., development of a new course, preparation of a syllabus), unpublished scholarly outcomes (e.g., experimenting with a new instructional practice, presenting to colleagues about a new instructional technique), and publications (e.g., classroom research publication, publication of a new pedagogical strategy). They posit that faculty engagement in the scholarship of teaching is visible through the second two categories. Activities in the first would be evaluated/rewarded under teaching. However, though they state that "a distinction between scholarly activities and scholarship undergirds these categories" (p. 141), all three categories are listed under the heading "The Scholarship of Teaching" in their inventory. Perhaps this is just semantics, but semantics matter. This double use of the term the "scholarship of teaching" (as an umbrella concept in the inventory and as specific outcomes that count as research/scholarship) may be confusing to some. The confusion is highlighted when we note that there are no scholarly activities under "The Scholarship of Discovery," only unpublished scholarly outcomes and publications. Why, given the conception of "scholarship of teaching" presented, are not scholarly activities, such as conducting a research study to ascertain new disciplinary knowledge, included under "The Scholarship of Discovery" heading?

Related to these issues is the need to maintain a balance. For most faculty members, SoTL would not and should not replace their traditional disciplinary scholarship, nor does it replace teaching or service. How do all these fit together? What are the priorities? How does someone do work in all these 
areas? How does this balance vary by institutional or department type or mission? How do we increase the fit between mission and the value of SoTL? We need career models for SoTL at various levels.

Fifth, we also must increase collaboration and sharing of SoTL work, including bringing new players in to the field. For example, we need to target future faculty, new faculty, and staff members involved in student learning. We have the challenge of involving students themselves in our SoTL work, beyond the role of research subject. For example, in a recent SoTL small grant request for proposals at Illinois State University, it was required that each proposal be submitted by a team including, at least, two faculty from the same discipline and one student.

Sixth, we have the challenge of synthesizing what we know, what we don't know, and what we need to know. That is, we have the challenge of setting appropriate SoTL research agendas both within and across disciplinary boundaries. Conversations and sharing at professional meetings (e.g., at AAHE) and special institutes (e.g., the ASA workshop on SoTL), or in journal article reviews and electronically, will be needed to discuss current knowledge and future research needs. There is the related challenge of helping faculty, staff, and students unfamiliar with this work to discover sources of information and learn new sets of literature and additional methodological skills through training, development, and mentoring.

Finally, we face a variety of ethical and methodological challenges in this work, challenges that can impact how the work is accomplished, received, and used. For example, how does SoTL work protect the privacy of, and avoid harm for, our student subjects and colleagues? When is it unethical to do a SoTL quasi-experiment where the control group fails to receive an intervention that is believed to enhance learning? We need to consider federal and local Institutional Review Board guidelines, the ethical codes of our disciplinary societies, the power relationships of faculty and students, and our own personal ethics in answering such questions. (See Hutchings, 2002b for a discussion of ethical issues and SoTL as well as a presentation of several "cases" in this area.)

What is the role of technology as both a topic and a tool in So'TL? In what ways, given practical and ethical limitations, can we improve the quality of the methods of our SoTL work and/or convince others that the work is worth paying attention to despite traditional methodological limitations (e.g., Cross \& Steadman, 1996) such as nonrandom samples or the lack of a control group?

Though advice has been offered related to some of these issues (e.g., Braxton, Luckey, \& Helland, 2002; Glassick, Huber, \& Maeroff, 1997), the use 
and impact of such advice has been limited. We are challenged to find ways over and around the many barriers to SoTL work, as well as to remove them.

\section{FUTURE VISIONS FOR THE SCHOLARSHIP OF TEACHING AND LEARNING}

What might a future vision of SoTL look like? A strong history of SoTL exists on many campuses and in other higher education organizations. Yet, to make significant progress that will impact student learning and development, and faculty lives, we must change the culture. Though this is becoming a worn out phrase, the idea remains true. This change must come on campus from both the grassroots and the upper administrative levels, as well as from various higher education organizations. We must consider factors that will increase the legitimacy of SoTL as work and as a social movement. For example, we can work, in different ways, with innovators and early and middle adopters of this work; be inclusive by recruiting new faculty, senior faculty, staff, and students; utilize highly respected, key faculty leaders; make use of existing governance structures and strategic plans to effect changes in value and reward; and provide adequate and useful faculty development, information, and resources for doing and using SoTL.

This cultural shift must include a change in our views of our roles as faculty and staff who work to enhance student learning. I believe that every instructor (broadly defined) who signs a contract to teach is ethically obligated to become at least a scholarly teacher and some will also choose to engage in SoTL. This is the case whether one teaches ten or 1,000 students, one or eight classes. Just as we do all we can to be scholarly in traditional areas of our disciplines, we must be scholarly about and (for some) practice scholarship in teaching and learning. This is part of what it means to be a professional, and the practice of SoTL is critical to the improvement of teaching and learning. For those involved in doing SoTL, in this vision of the future, reward structures throughout the institution will truly recognize the value of this work.

In this future vision, we need to consider various models of doing, supporting, understanding, and evaluating SoTL work. The models will vary by institutional, disciplinary, or departmental culture and structure. We will need models at multiple levels: individual career, department, discipline, institution, and national. On the one hand, we could continue to work toward common definitions, standards, supports, career models, etc. for SoTL in higher education that cut across contexts and fit more traditional disciplinary scholarship. That is, we could work toward a SoTL that is simply "S." Glassick, Huber, and Maeroff (1997), for example, offer general standards for scholarly 
work, including clear goals, adequate preparation, appropriate methods, significant results, effective presentation, and reflective critique.

In the 100-page Scholarship in the Postmodern Era: New Venues, New Values, New Visions (Zahorski, 2002), the scholarship of teaching and learning is discussed explicitly only once in a brief section and alluded to in only two or three other places. None of the chapters address SoTL as the primary topic. How do we interpret this? Is SoTL still thought of as different or less legitimate and, thus, not worthy of space in this volume? Or, have we made such great progress in the transition from SoTL to "S" that SoTL holds an equal place with other scholarship and is presumed to be a part, implicitly, of the entire discussion in this volume?

On the other hand, it is more likely that SoTL will remain somewhat distinct from traditional disciplinary scholarship. Individuals, departments, and institutions will view this work and organize this work in various ways. For some, SoTL will be their primary line of research; for others it may be a secondary area. SoTL work may be done at only some stages in a faculty member's career cycle. Some might work on SoTL only during a sabbatical; others may integrate it into their ongoing professional life. Some departments may reward SoTL within their existing, traditional reward structures; others may need to create new, special roles or assignments. Huber (2001) illustrates some of these models and paths for doing SoTL work with specific individual case examples. Brief discussions and examples of institutional models and national collaborations have also been offered (Cambridge, 2002). As I finish this chapter, a discussion about the possibility of forming a national organization for SoTL is just beginning. Additional systematic research is needed to assess the nature and outcomes of the models currently used to structure this work at all levels.

A small number of individuals or small teams of faculty members in relative isolation accomplish much of the current SoTL support and work on many campuses. In a vision of the future, we will increase the breadth of involvement in SoTL as well as collaboration on SoTL, both within disciplines and in what Huber and Morreale (2002) call the interdisciplinary trading zones. We will work to broaden the base and increase the diversity of people working together to do and use SoTL work through both research support and development activities. Live and electronic SoTL communities can be created on campuses via brown bags, symposia, lunches, small grants that require teams of investigators, workshops, electronic discussion lists, web pages, etc. We can begin to connect these communities across campuses and disciplines with the help of disciplinary societies, CASTL, and AAHE, for example. 
Clearly, a future vision of SoTL includes improvements in development and support for such work. There are many possible strategies (many already in use at a variety of institutions and organizations) for new services and structures to help faculty, staff, and students do this work and do it well (see, also, Kreber, 2001b; Lacey, 1983; Shulman, 1999). Those involved in faculty development should consider managing SoTL small grant programs, designing an institute or course on doing and publishing SoTL work, helping to form and facilitate SoTL writing circles, providing resources (books, journals, web sites) to assist those doing SoTL work, editing draft SoTL grants or articles, finding SoTL mentors, assisting in the identification of SoTL funding sources, and serving as a resource for college and department personnel committees on evaluating and rewarding So'TL work.

\section{Conclusion}

The way to a faculty member's heart is through his or her discipline, thus, many, though certainly not all, of these efforts should focus on the department or disciplinary level, making use of the culture (i.e., language, values, informal norms about teaching and scholarship, mechanisms for communication and social change) and the unique characteristics of the discipline (e.g., the ratio of content or skills, outside accreditation body or not, degree or speed of change in knowledge) (Healey, 2000; Jenkins, 1996; Shulman, 1993).

As noted earlier, another vision of the future is that we will routinely use and apply what we find in our SoTL work to pedagogical, curricular, and institutional reform in our institutions. This is the key purpose and benefit of SoTL work. SoTL work can help us implement our missions and strategic plans, reinvigorate faculty members tired of the status quo or the work they have been doing for years, and enhance student outcomes. Those in faculty and organizational development roles should consider doing or supporting work that uses SoTL findings, if they are not already. This could mean serving on strategic planning and related committees, sharing useful studies and results from SoTL work across campus, and working with department personnel to help them see the implications of, and apply, specific SoTL findings. Such work must also be shared outside our institution. Thus, we need to continue the conversation about SoTL that is occurring at the regional and national levels, both discipline-specific and in the broader higher education arena. The soul of SoTL is its public and applied nature.

Finally, assessing the impact of SoTL work is a critical part of any future vision of So'TL. What outcomes would we anticipate from efforts to further encourage, support, reward, and use SoTL? We would expect, for example, in- 
creases in reflection and public discussion of teaching and learning on campus, increases in the quantity, quality, and visibility of SoTL work on campus, use of SoTL to assess what we are doing, improved application of SoTL results and their implications to improve teaching and learning in higher education, changes in the reward structure related to SoTL, and increased visibility of faculty and their SoTL work on regional and national levels. If truly successful, perhaps we may see major investments in SoTL, including large grant programs or endowed chairs in SoTL. Finally, and most importantly, attention to the scholarship of teaching and learning will remind us to always ask the key question when making any decision at the university: What is the impact on student learning?

\section{Note AND ACKNOWLEDGMENTS}

This chapter is an elaboration of remarks made at the installation of the Cross Endowed Chair in the Scholarship of Teaching and Learning, Illinois State University, Normal, Illinois, July 2002. I would like to thank Paul Baker, Pat Hutchings, and K. Patricia Cross for their thoughtful comments on earlier versions of this chapter.

\section{REFERENCES}

Astin, A. W. (1993). What matters in college: Four critical years revisited. San Francisco, CA: Jossey-Bass.

Baker, P. (1980). Inquiry into the teaching-learning process: Trickery, folklore, or science? Teaching Sociology, 73), 237-245.

Baker, P. (1985). Does the sociology of teaching inform Teaching Sociology? Teaching Sociology, 12(3), 361-375.

Baker, P. (1986). The helter-skelter relationship between teaching and research. Teaching Sociology, 14(1), 50-66.

Baker, P. (2002, July). Teacher-scholars and the scholarship of teaching in the research-intensive university: reflections on a slow revolution. Paper presented at Mission, Values, and Identity: A National Conference for Carncgie Doctoral/Research Intensive Institutions, Normal, IL.

Bass, R. (1999, February). The scholarship of teaching: What's the problem? Invention: Creative Thinking about Learning and Teaching, 1(1), 1-10.

Boyer, E. (1990). Scholarship reconsidered: Priorities of the professoriate. San Francisco, CA: Jossey-Bass. 
Braxton, J. M., Luckey, W., \& Helland, P. (2002). Institutionalizing a broader view of scholarship through Boyer's four domains (ASHE-ERIC Higher Education Report, 29 [2]). San Francisco, CA: Jossey-Bass.

Braxton, J. M., \& Toombs, W. (1982). Faculty uses of doctoral training: Consideration of a technique for the differentiation of scholarly effort from research activity. Research in Higher Education, 16(3), 265-282.

Brookfield, S. D. (1995). Becoming a critically reflective teacher. San Francisco, CA: Jossey-Bass.

Cambridge, B. (2001). Fostering the scholarship of teaching and learning: Communities of practice. In D. Lieberman \& C. Wehlburg (Eds.), To improve the academy: Vol. 19. Resources for faculty, instructional, and organizational development (pp. 3-16). Bolton, MA: Anker.

Cambridge, B. (2002). Linking change initiatives: The Carnegie Academy for the Scholarship of Teaching and Learning in the company of other national projects. In D. Lieberman \& C. Wehlburg (Eds.), To improve the academy: Vol. 20. Resources for faculty, instructional, and organizational development (pp. 38-48). Bolton, MA: Anker.

Chickering, A. W., \& Gamson, Z. F. (1987, June). Seven principles for good practice in undergraduate education. AAHE Bulletin, 39, 3-7.

Chin, J. (2002). Is there a scholarship of teaching and learning in Teaching Sociology? Teaching Sociology, 30(1), 53-62.

Cross, K. P., \& Steadman, M. H. (1996). Classroom research: Implementing the scholarship of teaching. San Francisco, CA: Jossey-Bass.

Darling, A. L. (2003). Scholarship of teaching and learning in communication: New connections, new directions, new possibilities. Communication Education, 52(1), $47-49$.

Eisenberg, A. (2002, August). Educational praxis: Linking the practice of teaching with the scholarship of teaching and learning. Paper presented at the American Sociological Association annual meeting, Chicago, IL.

Glassick, C. E., Huber, M. T., \& Maeroff, G. I. (1997). Scholarship assessed: Evaluation of the professoriate. San Francisco, CA: Jossey-Bass.

Goldsmid, C. A., \& Wilson, E. K. (1980). Passing on sociology: The teaching of a discipline. Belmont, CA: Wadsworth.

Healey, M. (2000). Developing the scholarship of teaching and learning in higher education: A discipline-based approach. Higher Education Research and Development, 192), 167-187. 
Huber, M. T. (2001). Balancing acts: Designing careers around the scholarship of teaching and learning. Change, 33(4), 21-29.

Huber, M. T., \& Morreale, S. P. (Eds.). (2002). Disciplinary styles in the scholarship of teaching and learning: Exploring common ground. Washington DC: American Association for Higher Education.

Hutchings, P. (2002a, March). Informal handout and remarks at the SoTL community of practice. Annual meeting of the American Association for Higher Education, Chicago, IL.

Hutchings, P. (2002b). Ethics of inquiry: Issues in the scholarship of teaching and learning. Menlo Park, CA: The Carnegie Foundation for the Advancement of Teaching.

Hutchings, P., \& Shulman, L. S. (1999, September/October). The scholarship of teaching: New elaborations, new developments. Change, 31(5), 10-15.

Jenkins, A. (1996). Discipline-based educational development. The International Journal for Academic Development, I(1), 50-62.

Kreber, C. (Ed.). (200la). Scholarship revisited: Perspectives on the scholarship of teaching and learning. New Directions for Teaching and Learning, No. 86. San Francisco, CA: Jossey-Bass.

Kreber, C. (2001b). The scholarship of teaching and its implementation in faculty development and graduate education. In C. Kreber (Ed.), Scholarship revisited: Perspectives on the scholarship of teaching and learning (pp. 79-88). New Directions for Teaching and Learning, No. 86. San Francisco, CA: Jossey-Bass.

Kreber, C., \& Cranton, P. A. (2000). Exploring the scholarship of teaching. The Journal of Higher Education, 71(4), 476-495.

Lacey, P. A. (1983). Revitalizing teaching through faculty development. San Francisco, CA: Jossey-Bass.

Martin, E., Benjamin, J., Prosser, M., \& Trigwell, K. (1999). Scholarship of teaching: A study of the approaches of academic staff. In C. Rust (Ed.), Improving student learning: Improving student learning outcomes (pp. 326-331). Oxford, England: Oxford Brookes University, Oxford Centre for Staff Learning and Development.

Mauksch, H. O., \& Howery, C. B. (1986). Social change for reaching: The case of one disciplinary association. Teaching Sociology, 14(1), 73-82.

McCarthy, J. D., \& Zald, M. N. (1977). Resource mobilization and social movements: A partial theory. American Journal of Sociology, 82(6), 1212-1241.

McKenna, J., Bickle, M., \& Carroll, J. B. (2002). Using scholarship to integrate teaching and research. Journal of Family o Consumer Sciences, 94(3), 39-45. 
Pascarella, E. T., \& Terenzini, P. (1991). How college affects students. San Francisco, CA: Jossey-Bass.

Paulsen, M. B., \& Feldman, K. A. (1995). Toward a re-conceptualization of scholarship: A human action system with functional imperatives. Journal of Higher Education, 6G(6), 615-640.

Pellino, G. R., Blackburn, R. T., \& Boberg, A. L. (1984). The dimensions of academic scholarship: Faculty and administrator views. Research in Higher Education, 20(1), 103-115.

Rice, R. E. (1992). Toward a broader conception of scholarship: The American context. In T. G. Whiston \& R. L. Geiger (Eds.), Research and higher education in the United Kingdom and the United States (pp. 117-129). Lancaster, England: Society for Research on Higher Education.

Richlin. L. (Ed.). (1993). Preparing faculty for the new conception of scholarship. New Directions for Teaching and Learning, No. 54. San Francisco, CA: Jossey-Bass.

Richlin, L. (2001, Summer). Scholarly teaching and the scholarship of teaching. In C. Kreber (Ed.), Scholarship revisited: Perspectives on the scholarship of teaching and learning (pp. 57-68). New Directions for Teaching and Learning, No. 86. San Francisco, CA: Jossey-Bass

Schön, D. A. (1983). The reflective practitioner: How professionals think in action. New York, NY: Basic Books.

Schön, D. A. (1987). Educating the reflective practitioner: Toward a new design for teaching and learning in the professions. San Francisco, CA: Jossey-Bass.

Schön, D. A. (1995). The new scholarship requires a new epistemology. Change, 276), 26-34.

Shulman, L. S. (1987). Knowledge and teaching: Foundations of the new reform. Harvard Educational Review, 36(1), 1-22.

Shulman, L. S. (1993, November/December). Teaching as community property: Putring an end to pedagogical solitude. Change, 25(G), 6-7.

Shulman, L. S. (1999). Visions of the possible: Models for campus support of the scholarship of teaching and learning. Retrieved April 28, 2003, from http://www.carnegie foundation.org/elibrary/docs/Visions.htm

Shulman, L. S. (2001). Remarks at the teaching symposium for the Cross Endowed Chair for the Scholarship of Teaching and Learning, Illinois State University.

Smelser, N. J. (1963). Theory of collective behavior. New York, NY: Free Press. 
Smith, R. (2001). Expertise and the scholarship of teaching. In C. Kreber (Ed.). Scholarship revisited: Perspectives on the scholarship of teaching and learning (pp. 69-78). New Directions for Teaching and Learning, No. 86. San Francisco, CA: Jossey-Bass.

Weimer, M. (1996). Why scholarship is the bedrock of good teaching. In R. J. Menges \& M. Weimer (Eds.), Teaching on solid ground: Using scholarship to improve practice (pp. 1-12). San Francisco, CA: Jossey-Bass.

Weston, C. B., \& McAlpine, L. (2001). Making explicit the development toward the scholarship of teaching. In C. Kreber (Ed.), Scholarship revisited: Perspectives on the scholarship of teaching and learning (pp. 89-98). New Directions for Teaching and Learning, No. 86. San Francisco, CA: Jossey-Bass.

Zahorski, K. J. (Ed.). (2002). Scholarship in the postmodern era: New venues, new values, new visions. New Directions for Teaching and Learning, No. 90. San Francisco, CA: Jossey-Bass.

\section{Contact:}

Kathleen McKinney

Cross Chair in the Scholarship of Teaching and Learning

Professor of Sociology

Box 3990

Illinois State University

Normal, IL 61790-3990

Voice (309) 438-7706

Fax (309) 438-8788

Email kmckinne@ilstu.edu

Kathleen McKinney is Cross Chair in the Scholarship of Teaching and Learning and Professor of Sociology at Illinois State University. She served from 1996 to 2002 as the Director of the Center for the Advancement of Teaching. She directs the CASTL program at Illinois State University and is a 2003-2004 Carnegie Scholar. She serves as a member of the American Sociological Association's Task Force on the Undergraduate Major and the ASA Department Resources Group. Currently, she teaches the Sociology Senior Experience course. She has numerous publications in the areas of sexual harassment in academia, personal relationships, and teaching and learning in sociology. 